\title{
Marketing mix 4p na polskim rynku książki
}

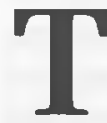

elkst ten jest próbą uporządkowania wiedzy o praktycznym zastosowaniu zasad marketingu na współczesnym polskim rynku książki. Nie pretenduje, oczywiście, do formulowania diagnoz i precyzowania programów na przyszłość, co (najczęściej w mikroskali) stanowi rutynowy zestaw czynności odpowiednich działów w firmach wydawniczych. Prezentując punkt widzenia obserwatora rynku niedysponującego wykształceniem ekonomicznym, choć posiadającego pewne doświadczenia pracownika i uczestnika rynku książki, dąży natomiast do usystematyzowania podstawowych pojęć z myślą o mniej lub bardziej typowych przedsięwzięciach polskich oficyn. Istotne okażą się wobec tego definicje i spostrzeżenia zawarte w pracach autorów, którzy dali zarys wiedzy ogólnej o marketingu, jak też stworzyli dzieła na wskroś praktyczne, udzielając porad wydawcom czy księgarzom, najczęściej z myślą o czytelnikach anglosaskich.

Nie chodzi tu o analizę ściśle naukową, choć refleksja teoretyczna o różnych zastosowaniach elementów marketingu winna mieć swój początek właśnie w próbie systematyzacji. Ten tekst stanowić ma raczej pewien przyczynek do przyszłych badań nad rynkiem ksiązki w Polsce, wylkraczających poza doraźny opis jego stanu współczesnego.

Literatura dotycząca ogólnych problemów marketingu jest bogata, a za klasyka w tej materii uchodzi Philip Kotler ${ }^{-1}$. Jeśli spytać jednak o aspekty odnoszące się do polskiego rynku książki, to mamy do czynienia niemal z deficytem opracowań. Zasłużoną popularnością wśród naszych wydawców cieszy się podręcznik Jacka Włodarczylka, współwłaściciela firmy konsultingowej BMR, specjalizującej się w szkoleniu pracowników oficyn i księgarzy. Marketing $8 p$ ma właściwie charakter skryptu pomocnego w doskonaleniu zawodowym, a nie choćby publicystycznego opracowania. Ale właśnie $z$ tych powodów zasługuje na szczególną uwagę, można go bowiem potraktować jako cenne źródło kreowane przez uczestnika rynku i zarazem jego obserwatora. Ważne tu będą nie tylko konstatacje nawiązujące do ustaleń teoretyków i przeformułowane ze względu na praktyczny cel szkoleń, lecz również argumenty uzasadniające konkretne porady i wskazówki. Zainteresowanie może wzbudzić także sam sposób myślenia autora o różnych aspektach marketingu².

Inny charakter ma skromne objętościowo i merytorycznie opracowanie Marcina Świtały Zachowania konsumentów i marketing na rynku książki. Nie sposób nie zauważć niewielkiej reprezentatywności zbadanej przez autora populacji respondentów - i $z$ tego powodu zasadnicze tezy pracy trudno uogólniać. Zasługuje jednak na uwagę wbrew pozorom dość ambitna próba skonfrontowania wiedzy teoretycznej z praktyką zachowań nabywców książek, odtworzoną na podstawie przeprowadzonych ankiet ${ }^{3}$. 
W pracy stworzonej na znacznie większą miarę Michał Zając zajął się natomiast pewnym fragmentem działań marketingowych oraz rynku wydawniczego. W swej Promocji ksiązki dziecięcej zaprezentował poczynania podmiotów polskich i zagranicznych (głównie anglosaskich). Autor wykorzystał zarówno naukową literaturę przedmiotu (odnosząca się nie tylko do spraw bibliologicznych i ekonomicznych, lecz także do uwarunkowań natury kulturowej, literackiej i socjologicznej), jak również teksty praktyków zamieszczone w prasie branżowej.

Z przekładów warto wymienić edycje firmy BMR. Są to tłumaczenia prac Johna Huenefelda, Alison Baverstock, Thomasa Wolla oraz opracowana pod auspicjami Departamentu Książki i Praw Wydawniczych UNESCO pozycja Jak osiągnąć sukces $w$ ksieggarstwie ${ }^{5}$. Te publikacje, zgodnie także $z$ profilem działania ich polskiego wydawcy, mają głównie charakter praktyczny: winny służyć pomocą czytelnikom potrzebującym wskazówek, przede wszystkim przedsiębiorcom prowadzącym działalność gospodarczą na rynku książli, a także pracownikom oficyn podejmującym decyzje merytoryczne. Ale ze względu na kompetencje autorów, wielość i skomplikowanie uwzględnionych problemów i z reguły bogatą egzemplifikację, a także pewien rozmach w narracji, książki te tworzą bardzo cenny zbiór, który - jak w przypadku przywołanej już pracy J. Włodarczyka, choć na nieporównanie większą skalę - wolno traktować jako zestaw opracowań, a w pewnym sensie i żródeł służących do rozważań o mararketingu na współczesnym rynku książki.

Jak zwykle wówczas, gdy rozważane są zagadnienia dotyczące ogólnej sytuacji polskiego ruchu wydawniczego, wymienić należy $z$ uznaniem opracowania Łukasza Gołębiewskiego Rynek ksiązki w Polsce..., dzięki swej periodyczności mające juz cechy obszernego i kompetentnie przygotowanego rocznika ${ }^{6}$. W cyklu dwuletnim wychodzą natomiast cenne prace Grazyny Straus i Katarzyny Wolff, prezentujące badania $\mathrm{IKiC} z \mathrm{BN}$ na temat czytelnictwa i zakupów ksiązek przez odbiorców indywidualnych ${ }^{7}$. Lakonicznie napisana, choć też bogata w informacje jest krótka synteza Bogdana Klukowskiego Ksiązka w świecie wspótczesnym, ważna w obiegu krajowym $\mathrm{m}$. in. ze względu na możliwość odnie sienia spraw polskich do sytuacji bardziej stabilnych i okrzepłych rynków wydawniczych, a także do pewnych tendencji w skali globalnej.

Jako uzupełnienie podstawowych lektur oraz materiał egzemplifikacyjny służły przy powstawaniu tego tekstu publikacje $z$ prasy branżowej, głownie z „Biblioteki Analiz” i „Notesu Wydawniczego”. Tytuły te tworzą w sumie dość solidne zaplecze informacyjne i merytoryczne dla środowisk zawodowo zajmujących się książką, choć niestety nie zawsze są tam należycie doceniane i wykorzystywane.

„(..) Marketingu nie wolno traktować jako robienia interesu kosztem nabywcy. Prawidłowy marketing ma nie tylko na celu bezpośredni sukces handlowy, lecz takze odgadnięcie rzeczywistych potrzeb i gustów różnych środowisk. Znany jest pogląd, że dobry marketing wymaga dobrej znajomości historii środowiska, do którego jest adresowany, a także jego psychiki, obyczajów, nawyków. Marketing wymaga po prostu wiedzy o świecie" - twierdzi Wacław Wilczyński ${ }^{9}$. W podobnym duchu wypowiada się Philip Kotler, akcentując zwłasz- 
cza zaspokajanie potrzeb indywidualnych i grupowych dzięki działaniom marketingowym. Podlkreśla tė̇, że reputacja i wiarygodność firm „pogrubiają ich portfele"10. Obaj autorzy zdają sobie jednak sprawę, iż nie wszyscy uczestnicy gry rynkowej myślą tak pozytywnie i podzielają ich poglądy. W innej swej pracy Kotler wspomina o wpływowych cynikach, uważających wiedzę marketingową „Za próbę nadania godności czemuś, co $z$ istoty jest ordynarną bójką"11.

Jesteśmy zatem pomiędzy biegunami skrajnych ocen. Nie wchodząc w istotę sporu (i niezależnie od tego, którą opcję wybierzemy), zauważmy tylko, iż przekonująco brzmi uwaga poczyniona przez inny autorytet - Petera Druckera - o tym, że powodzenie w biznesie zależy ostatecznie nie od producenta, lecz klienta ${ }^{12}$. Choć i tu można wnieść pewne zastrzeżenia - powrócę do tej kwestii w końcowych partiach tekstu.

Dyskusje o zabarwieniu aksjologicznym dotyczą nie tylko celów, którym marketing ma służyć. Koncentrują się także na samej jego istocie. Pojęcie wywodzi się od angielskiego rzeczownika market i prawdopodobnie w znanym nam dziś znaczeniu zostało uzyte po raz pierwszy na początku ubiegłego stulecia. Jak zauważa Andrzej Sznajder, nie udało się go przetłumaczyć na język polski ani na inne języki. Według tego autora próbowano to kiedyś uczynić w... NRD, ale termin Marktarbeit (praca na rynku) nie przyjął się ${ }^{13}$.

A. Baverstock, z pozycji autorki zajmującej się praktycznym zastosowaniem marketingu na rynku książki, pisze chyba nie bez ironii, że naukowcom nie udało się pogodzić w kwestii definicji - i rzeczywiście wymowny jest przykład tekstu Keitha Crosiera, w którym omówione zostało ponad pięćdziesiąt definicji proponowanych przez różnych autorów, jednak bez efektu w postaci czegoś na ksztalt wspólnego mianownika ${ }^{14}$.

P. Kotler powiada o marketingu jako „procesie społecznym i zarządczym”, przy czym, cytując Raya Coreya, uznaje, że ów proces polega na przystosowaniu się przedsiębiorstwa do swego otoczenia w sposób twórczy i zyskowny ${ }^{15}$. J. Huenefeld natomiast, wyciągając praktyczne wnioski $z$ rozmaitych wskazówek teoretyków, cel ostateczny marketingu widzi po prostu w „maksymalizacji całkowitej sprzedaży netto (po potrąceniu rabatów i zwrotów)"16.

$Z$ pojęciem marketingu wiąże się koncepcja orientacji marketingowej, o której pisze m.in. A. Sznajcler. Uznaje on, iż przedsiębiorstwo może kierować się orientacją produkcyjną i właśnie marketingową. W przypadku tej pierwszej wszystko ocenia się przez pryzmat maksymalizacji produkcji. Ta druga polega natomiast na osiągnięciu możliwie największego zysku - firma produkuje to, co może korzystnie sprzedać. Charakterystycznie zostala te $\dot{z}$ zarysowana m.in. rola badań rynku - w ramach orientacji produkcyjnej dąży się do „określenia reakcji nabywców," marketingowej zaś - do „określenia potrzeb nabywców i sposobów ich zaspokojenia" ${ }^{17}$. Na marginesie dodajmy, że przeciwstawienie obu wspomnianych orientacji wydaje się bardzo istotne ze względu na zrozumienie procesu transformacji gospodarki, jaki dokonał się w Polsce, w tym również - w formie do dziś niezakończonej - na rynku książki.

Powróćmy jednak do zasadniczego wątku. Nie kusząc się o rozstrzygnięcie dylematów i dyskusji prowadzonych przez autorów ujęć teoretycznych, ale przecież i poradnikowych - wyłącznie dla potrzeb tego tekstu, niech wolno będzie zaproponować następującą roboczą definicję: 
„Marketing jest procesem polegającym na badaniu i świadomym kształtowaniu rynku oraz działań przedsiębiorstwa na tymże rynku - w celu wywarcia optymalnego wpływu na rezultaty sprzedaży prowadzonej przez to przedsiębiorstwo". Definicja ta wydaje się uwzględniać złożoność pojęcia marketingu, jego aspekty społeczne i - może przede wszystkim - praktyczne zadania przed nim stawiane.

W teorii i praktyce wyróżnia się też zbiory różnych elementów (instrumentów, narzędzi) marketingu, użytecznych w dążeniach do maksymalizacji zysku na rynku docelowym. „Odpowiedni dobór tych elementów marketingu, czy też system decyzji dotyczących tych zagadnień - ma nazwę marketing mix" - wyjaśnia A. Sznajder ${ }^{18}$. P. Kotler zaś uznaje, że marketing mix to kluczowa koncepcja w nowoczesnej teorii marketing ${ }^{19}$.

Pojęcie marketingu mix 4p wprowadził natomiast i spopularyzował Jerome E. Mc Carthy. Owe 4p tworzą: produkt (product), cena (price), kanaly dystrybucji (place) i promocja (promotion). Eksponuje się tu przede wszystkim punkt widzenia producenta (sprzedawcy) i jego decyzje odnośnie oddziaływania na potencjalnych nabywców ${ }^{20}$.

Przez zwolenników formuła ta $z$ czasem została rozbudowana aż do $8 \mathrm{p}-$ uwzględnia się tu jeszcze takie kategorie, jak czas (period), ludzie (people), opakowanie (pack), zysk (profit) ${ }^{21}$. Krytycy natomiast twierdzą, że koncepcja 4p czy $8 \mathrm{p}$ jest $\mathrm{w}$ istocie wtórna wobec teorii uwzględniającej przede wszystkim punkt wiclzenia konsumenta. Robert Lauterborn zaproponowal nawet 4c (wartość dla klienta - customer value, koszt ponoszony przez klienta - customer cost, wygodę - convenience i komunikację - communication) nie tyle jako alternatywę, co raczej koncepcję nadrzędną wobec 4p. Była też propozycja, by całość elementów marketingu mix podzielić na dwie wielkie grupy - ofertę oraz metody i narzędzia. Inni postulowali natomiast (przyznać trzeba, że $z$ poczuciem zdrowego rozsądku) ucieczkę $z$ niewoli $4 p$, proponując nazywanie poszczególnych elementów rzeczownikami zaczynającymi się w języku angielskim niekoniecznie na literę $p^{22}$.

Zarzut pewnej nadreprezentacji spraw pozostających prostą konsekwencją uznania głównie punktu widzenia producenta zdaje się do pewnego stopnia podzielać P. Kotler. Niejako na marginesie zauważył on też, że można wyróżnić dziesiątki narzędzi marketingu mix ${ }^{23}$. W tej drugiej sprawie $z$ pewnością ma rację. Pierwszy $z$ zarzutów daje się natomiast osłabić stwierdzeniem, że podstawowe pojęcie marketingu uwzględnia przecież głównie działania producenta (a nie adresata jego produktów), nie ma zatem powodów, by wedlug innych kryteriów obmyślać formułę marketingu mix.

Koncepcja marketingu mix 4p ze swego czasu nowatorskiej przeistoczyła się już dziś $w$ tradycyjną. Wciąż jednak funkcjonuje $w$ podstawowej literaturze przedmiotu. Jest chyba w sumie nieco łatwiejsza do obrony niż formuła $8 \mathrm{p}$. Po pierwsze - jako bardziej ogólna (diabeł przecież tkwi w szczególach - więc im mniej szczegółów, tym koncepcja bardziej spójna). Po drugie - mniej sztuczna także pod względem semantycznym (bo 4 p to po prostu mniej niż $8 p$, więc i sztuczności - choćby niewoli wobec litery $p$ tu mniej). Prezentowany tekst nawiązuje więc właśnie do koncepcji marketingu mix 4p. 
P. Kotler uważa produkt za podstawowe narzedzie marketingu mix. Określa go jako „cokolwiek, co może znaleźć się na rynku, zyskać uwagę, zostać nabyte, użyte lub skonsumowane, zaspokajając czyjeś pragnienie lub potrzebę". W zbiorze produktów wyróżnia dobra fizyczne, usługi, osoby, miejsca, organizacje i idee ${ }^{24}$.

W sprawach wydawniczych produkt $z$ reguly odruchowo kojarzony jest z pojedynczą książką, choć może to być również np. seria. Zasygnalizujmy też na marginesie (raczej $z$ obowiązku niż przekonania co do konieczności szerszego elssploatowania problemu) nieśmiertelne pytanie, czy książkę w ogóle wolno kojarzyć z produktem, przecież stanowi ona rzekomo wyłącznie clobro kultury. Rzecznicy takich opinii najczęściej po prostu uznają orientacje marketingową w świecie publikacji za przejaw ogólnego upadku wartości w dobie kultury masowej. Spotkać się można z pewnym radykalizmem myślenia i sformułowań również z drugiej strony; np. dość niewinne stwierdzenie, że postrzegane wlaśnie jako produkt ksiązki mają swoją specyfikę, A. Baverstock uzna za ,jeden z najbardziej szkodliwych frazesów, jaki kiedylkolwiek wymyślono"25. M. Świtała, odnosząc się do owych kontrowersji, pisze zaś ze spokojem: „Książka, jak każdy produkt, posiada określoną formę materialną, oprócz tego zawiera jednak w sobie pewną informację o charakterze estetycznym czy filozoficznym. Ogólnie mówiąc, jest dobrem kulturalnym jak obraz bądź rzeźba" ${ }^{26}$.

Istotnie, handluje się dziełami wybitnych plastyków, w obrocie międzynarodowym są także m.in. utwory nagrodzone prestiżowymi nagrodami literackimi. Nie ma powodów, by z tego względu odmawiać im zarówno przynależności do sfery kultury wysokiej, jak też do pełnienia roli produktów w dziedzinie gospodarki.

Z innych dóbr fizycznych obecnych na rynku wydawniczym, lecz różnych od tradycyjnej książki, warto wspomnieć publikacje wymiennokartkowe, sprzedawane $w$ formie segregatorów $\mathrm{z}$ zawartością aktualizowaną co najnniej kilka razy w roku. Chętnie specjalizują się w tym zwłaszcza oficyny zajmujące się literaturą prawniczą, poradnictwem dla przedsiębiorców czy księgowych. W Polsce jako pierwsze wprowadziło je $A B C$ - dziś część grupy Polskich Wydawnictw Profesjonalnych, stanowiącej własność koncernu Wolters - Kluwer. I choć parę lat temu PWP zaniechały dalszych inwestycji w tej dziedzinie, świadome pogłębiającego się nasycenia rynku ${ }^{27}$, to przecież rozwój takich firm, jak Wiedza i Praktyka czy Forum świadlczy o wciąż niemałych możliwościach ekspansji na tym polu ${ }^{28}$.

Produktami - dobrami fizycznymi coraz bardziej istotnymi dla rynku książki są m.in. publikacje elektroniczne. Specjalizują się w nich również wydawnictwa fachowe (choć nie tylko one); np. znany z solidności CH Beck, mimo silnej konkurencji, odniósł sukcesy oferując system informacji prawnej Legalis (elektroniczna baza aktów prawnych) oraz uzupełniające go oprogramowanie Kancelaris (przydatne do prowadzenia firm prawniczych) ${ }^{29}$.

Przy tej okazji z reguły wymienia się jednak glównie oficynę Young Digital .Poland - największego w Polsce producenta książelk elektronicznych, specjalizującego się w publikacjach edukacyjnych, kursach języków obcych, słownikach. I choć YDP nigdy nie wydał żadnej książki w postaci tradycyjnej, to jed- 
nak jest stale uwzględniany w rankingach wydawnictw „Rzeczpospolitej” (E. Gołębiewski, autor owych rankingów, świadomy nietypowości sytuacji, zauważa brak jasnych kryteriów pozwalających zdefiniować książkę elektroniczną i odróżnić ją np. od gier komputerowych) ${ }^{30}$. W 1998 r. YDP otrzymał też nominację do Nagrody Sezonu Wydawniczo-Księgarskiego "Ikar"31.

48\% udziałów w YDP kupił fiński koncern Werner Sonderstrom, wspomniałem już o wcześniejszym wykupie $A B C$ przez Wolters Kluwer - i nie są to przecież odlosobnione przykłady transakcji zawieranych na rynku książki. Pokazują one, że produktem może być także samo wydawnictwo - podobnie jak firmy prowadzące działalność innego typu, np. hurtownie czy księgarnie.

Usługi wobec wydawców polegają głównie na świadczeniach prepress, druku, handlu hurtowym czy detalicznym, a w sprawach bardziej codziennych w ogóle dla działalności gospodarczej, np. w obsłudze księgowej czy prawnej wykonywanej często na zewnątrz firm (outsoursing). Ale jako działalność usługową można określić też organizację targów książki - tak postrzega ją np. Peter Weichaas, wieloletni szef Frankfurter Buchmesse, największej tego typu imprezy na świecie ${ }^{32}$. Mimo popularnego pogląclu o powszechnym kryzysie targów książki, zapotrzebowanie na takie usługi wciąż w środowisku wydawniczym istnieje $^{33}$ - na rynku krajowym dowodzi go m.in. rozwój Targów Książki w Krakowie $^{34}$.

Jeśli chodzi o pozostałe typy produktów, to wspomnijmy tylko, iż osoba jako produkt na rynku wydawniczym to przede wszystkim autor - wiadomo że oficyny zabiegają o stałą współpracę znanych twórców, ale też skore są do rywalizacji na tym polu, w miarę potrzeb i swych możliwości nie wahając się proponować bardziej korzystnych warunków niz konkurencja ${ }^{35}$. Gdy w gre wchodzi sprzedaż firmy, istotne mogą być natomiast kompetencje personelu.

Są również miejsca, które $z$ perspektywy interesów prowadzonych $w$ dziedzinie książki uznać można za produkty. Organizatorzy wspomnianych targów w Krakowie na pewno znakomicie wykorzystali wszelkie atuty podwawelskiego grodu, począwszy od jego klimatu kulturalnego, a skończywszy na infrastrukturze gastronomicznej. Także Warszawa jako stolica, największe miasto w kraju, położone w jego centrum - nadaje się do roli najważniejszego polskiego ośrodka wydawniczego. Trochę wbrew kryzysowi, który przeżywają Krajowe Targi Książki, wolno uznać, ̇̇e ich stołeczność może być jednak atutem (jeśli już nie dla imprezy o charakterze klasycznych targów, to przynajmniej dla kiermaszu). Z większą pewnością da się to powiedzieć o „Edukacji”.

Organizacje, których nazwa może odgrywać pewną rolę marketingową, funkcjonują także w realiach naszego kraju. Szyld Polskiej Izby Książki, nawet przy uwzględnieniu przynajmniej części zarzutów podnoszonych wobec niej w środowisku branżowym, $z$ pewnością ma znaczenie np. wówczas, gdy widnieje w ofercie proponowanych wydawcom szkoleń; okazal się ważny także m.in. podczas negocjacji dotyczących przesylek kurierskich wydawców. Stowarzyszenie Wydawców Katolickich jako organizator targów książki również może stanowić rolę gwaranta ich poziomu i spójności światopoglądowej.

Idee przyświecające działaniom tego rodzaju stowarzyszen, jak i zrzeszajacych się w nich edytorów, też pełnią niekiedy rolę produktu. Widać to wyraźnie podczas wspomnianych przed chwilą Targów Wydawców Katolickich, widać 
i po efektach pracy jednoznacznych ideowo firm, jak oficyny Polskie Wydawnictwo Encyklopedyczne czy Nortom lub księgarnia Antyk.

Ustalenia teoretyków marketingu mix odnośnie produktu bez trudu dadzą się więc odnieść do spraw książki. Są jednak zagadnienia wymykające się takin klasyfikacjom. Wskazać można np. obrót prawami autorskimi, bardzo istotny dla działalności wydawniczej - posiadanie w swej gestii możliwości udzielania licencji czy wyrażania zgody np. na przekład albo wznowienie $z$ pewnością jest przecież produktem - i to często zajmującym bardzo istotną pozycję $\mathrm{w}$ bilansach.

Ze spraw związanych z funkcjonowaniem produktu w literaturze przedmiotu zwraca się uwagę na znak towarowy (markę) i opakowanie. A. Sznajder podkreśla, że ów znak nie tylko pozwala odróżnić clany towar od oferty konkurencji, ale w wypadku renomowanych firm stanowić może dla konsumentów gwarancję jakości: „nabywcy tworzą sobie pewien obraz (image) produktu danej marki i jego producenta"36. Na rynku wydawniczym dotyczy to przerle wszystkim logo wydawcy, mającego szczególne znaczenie - jak się wydaje - w publikacjach fachowych, specjalistycznych oraz encyklopedycznych, czyli w tych segmentach, w których publiczność jest $z$ reguły kompetentna i potrafi określić swe wymagania merytoryczne.

Istotna jest rola opakowania w marketingowej koncepcji produktu, według A. Sznajdera opakowanie jest nawet jego częścią ${ }^{37}$. J. Wloclarczyk twierdzi, że na opakowanie książki skłaclają się format, objętość i okłackaa ${ }^{38}$, na pewno podkreślić wypada istotne w tym miejscu rozróżnienie między obwolutą a okładką traktowanymi przez wspomnianego autora jako całość. Zauważa on natomiast m.in., że w niektórych sektorach czytelnicy preferują publikacje określonego formatu i objętości (inne oczekiwania mają pod tym wzglęclem np. miłośnicy literatury pięknej, inne - np. nabywcy książek naukowych). Wracając natomiast do okładki (czyli okładlki i obwoluty): J. Włodarczyk uznaje ją za podstawową formę autopromocji książki, mogącą mieć istotny wpływ na wysokość sprzedaży. Przestrzega też przed zaniedbaniem kwestii odpowiedniego wykorzystania grzbietu - puste grzbiety utrudniają identyfikację książki np. na półkach księgarni ${ }^{40}$. Dodajmy, że zdarzają się tu również błędy w sztuce edytorskiej (jeśli tekst drukowany jest wzdluz grzbietu, powinien być skomponowany „od góry do dołu", nie odwrotnie) ${ }^{41}$.

Ważna $z$ marketingowego punktu widzenia jest także decyzja w kwestii, czy wydać tytuł w oprawie twardej, czy mięklkiej - a zclarza się przecież, że publikuje się go i w jednej, i w drugiej. Na rynku amerykańskim ukazuje się mniej więcej tyle egzemplarzy hard cover, co paperback, a według badań przeprowadzonych przez kolonską firmę doradztwa przedsiębiorczości większość księgarzy niemieckich uważa, że przyszłość należy do książki kieszonkowej ${ }^{42}$.

Teoretycy i praktycy chętnie posługują się pojęciem cyklu życia produktu. A Sznajder określa go jako „stopień wprowadzenia towaru na dany rynek” i wyróżnia następujące fazy owego cyklu: badania wstępne, wprowadzenie produktu na rynek, wzrost sprzedaży, nasycenie rynku, spadek sprzedaży ${ }^{43}$.

J. Wlodarczyk natomiast odnosi się już bezpośrednio do spraw wydawniczych. W ślad za innymi opracowaniami odmiennie nazywa poszczególne fazy (choć podobnie postrzega ich istotę) i każdej $z$ nich przypisuje określony typ 
nabywców: faza wprowadzenia - pionierzy; faza wzrostu - zwolennicy; faza rozwoju - wczesna większość; faza nasycenia - późna większość; faza wycofania opieszali ${ }^{44}$.

Zdaniem A. Sznajdera, uniwersalna krzywa sprzedaży osiąga najwyższy poziom w fazie dojrzałości produktu (nasycenie rynku). Autor ten lapidarnie określa optymalne zachowanie się przedsiębiorstwa: „celowe jest maksymalne skrócenie fazy wprowadzenia towaru na rynek, przedłużenie fazy wzrostu i nasycenia oraz opóźnienie rozpoczęcia fazy spadku sprzedaży;" zaznacza przy tym, jak istotne są badania wstępne ${ }^{45}$. P. Kotler natomiast akcentuje potrzebę elastycznego traktowania poszczególnych elementów marketingu mix - zwłaszcza w fazie osiągnięcia przez produkt dojrzałości ${ }^{46}$. J. Włodarczyk zaś uznaje, że książki z reguły najlepiej sprzedaje się pod koniec fazy rozwoju i na początku fazy nasycenia ${ }^{47}$.

P. Kotler radzi, by nie sprzedawać jedynie produktu:

„Harley Davidson sprzedaje coś więcej niz tylko motocykl. Sprzedaje doświadczenia związane $z$ posiadaniem motocykla. Zapewnia członkostwo w pewnej społeczności. Organizuje wyprawy po przygodę. Sprzedaje styl życia. Jego produkt poszerzony to coś znacznie więcej niż sam tylko motocykl" ${ }^{\text {"48. }}$.

Zauważmy, że wbrew pozorom przynajmniej pod tym względem wydawcy książek nie różnią się tak bardzo od firm takich jak Harley Davidson. Też sprzedają coś więcej niż „tylko" treść publikacji. Oferują poczucie przynależności do warstw społecznych o wysokim poziomie wiedzy i kultury. Proponują przygode intelektualną (książki naukowe, eseistyka, filozofia, literatura piękna wysokiej próby) czy emocjonalną (thrillery, romanse). Sprzedają styl żcia osób wyrastających ponad przeciętną w sferach nieobojętnych przeciez dla poczucia własnej wartości wielu spośród nas. Książłka jako produkt rozszerzony ma więc również swoje atuty ${ }^{49}$. Inną sprawą pozostaje, na ile ogół nabywców na poszczególnych rynkach wewnętrznych jest na nie czuły.

Kolejny element marketingu mix $4 p$ to cena. A. Sznajder rozpoczyna wywód na jej temat od ogólnej uwagi, że powinna się ona mieścić pomiędzy dwoma wyznacznikami. $Z$ jednej strony: poziom kosztów poniesionych przez producenta plus minimalny zysk; $z$ drugiej: najwyższa $z$ sum możliwych do zaakceptowania przez nabywców produktu. Sa clwie podstawowe metody ustalania ceny: kosztowa i rynkowa. Ta pierwsza bierze pod uwagę wszelkie koszty oraz kalkulowany zysk. Ta druga opiera się głównie na analizie cen konkurencji. Pod tym względem metoda rynkowa kojarzy się $z$ orientacją na konkurencję - jedną $z$ podstawowych orientacji cenowych. Inna zwana jest orientacją na realizację celów finansowych - cena produktu wkomponowana jest w ogólną strategię przedsiębiorstwa, zakładającą osiągnięcie celów bardziej zasadniczych, np. zysku o konkretnie określonym wymiarze czy stabilizacji w segmencie niszowym. Orientacja na nabywców polega natomiast na przyjęciu spodziewanej reakcji klientów za podstawową przesłankę określenia ceny przez przedsiębiorstwo ${ }^{50}$.

J. Włodarczyk, pisząc swój podręcznik, uważał, że w tej dziedzinie wśród polskich wydawców szczególnie popularne są techniki oparte na kosztach, co choćby w wyniku pomijania realnej sytuacji rynkowej - przyczynia się do edycji deficytowych tytułów ${ }^{51}$. W parę lat po ukazaniu się Marketingu wydawniczego $8 p$ sytuacja jest już zapewne trochę inna, bo rynek w wyniku recesji stał się 
jeszcze bardziej konkurencyjny. Mało prawdopodobne wydaje się zatem, by w oficynach nie brano pod uwagę decyzji rywalizujących podmiotów. Jak podaje Ł. Gołębiewski, średnia cena książki (bez uwzględniania podręczników szkolnych) w Polsce na przestrzeni ostatniego badanego roku (2002-2003) wzrosła minimalnie ( $z$ 28,8 do 29,1 zł), właściwie w granicach błędu statystycznego. Analizując przyczyny (a przypomnijmy, że autor jest nie tylko dziennikarzem, ale i wydawcą), eksponuje co prawda głównie obniżenie kosztów edycji. Jako przykłady pozytywne przytacza jednak równiez decyzje wydawców o publikowaniu poczytnych powieści $w$ dwóch wersjach, o których była już mowa: clroższej oraz kieszonkowej - w małym formacie, na lichym papierze, a w związku z tym znacznie tańszej, uwzględniającej nie tylko mniejsze opłaty uiszczane przez producenta za usługi poligraficzne, ale też i realne możliwości nabywcze klientów. Praktyka powszechna na Zachodzie zdaje się wreszcie przyjmować i na naszym rynku ${ }^{52}$.

Wedle popularnego wśród czytelników poglądu, książki są w Polsce za drogie. Opinię tę podzielają niektórzy uczestnicy rynku, np. Jacek Olesiejuk, współwłaściciel ważnej firmy dystrybucyjnej ${ }^{53}$. Nie zawsze jednak tak było. Jeszcze kilka lat temu Grzegorz Boguta, ówczesny prezes PIK i szef PWN, publicznie twierdził, ze nasze społeczeństwo zaakceptowało juz europejski poziom cen wielu towarów (także codziennego użytku, np. past do zębów czy proszków do prania), z czasem będzie zmuszone więc pogodzić się $z$ wyższymi cenami ksiązek ${ }^{54}$. Dzisiaj, po doświadczeniach recesji, świadomość podstawowego znaczenia możliwości finansowych nabywców wydaje się wśród edytorów i księgarzy powszechna. Wnioski przez nich stąd wyciągane to sprawa odrębna, ale na ogół malo kto dązy do maksymalizacji cen za tytuły ze swej oferty.

Autorzy podręczników marketingu - choć oczywiście zalecają uwzględnianie punktu widzenia odbiorcy końcowego i spodziewanych reakcji pośredników sprzedaży oraz konkurentów - uważają cenę ze element elastyczny. P. Kotler np. powiada, że dla wielu nabywców „cena jest wskaźnikiem jakości”. Podaje on przykłady wzrostu sprzedaży osiąganego po podwyżce ceny - mechanizm ten clziałać ma zwłaszcza wtedy, gdy w grę wchodzą produkty „nieobojętne dla naszego ego" ${ }^{\prime 25}$.

Książka na pewno nie jest produktem obojętnym dla naszego ego. Zaznaczmy jednak również, że zwłaszcza w warunkach polskich trudno porównywać mechanizmy jej sprzedazy ze zbytem samochodów wysokiej klasy czy eleganckich kosmetyków. Pod tym względem daje się zauważyć pewne analogie co najwyżej w segmentach publikacji luksusowych, np. ekskluzywnych edycji ilustrowanych. J. Olesiejuk natomiast w juz przytoczonej i innych krytycznych wobec wydawców wypowiedziach nawiązuje głównie do problemu cen książek „Zwyczajnych" pod względem edytorskim, zwłaszcza bestsellerów i w ogóle popularnych edycji.

W branżowych dyskusjach uczestników polskiego rynku powraca pytanie: czy ceny książek powinny pozostać wolne, czy też należy ustawowo nakazać drukowanie ceny detalicznej - i w efekcie spowodować, by w każdej księgarni ta sama edycja kosztowała tyleż samo. Więlkszość dawnych krajów Unii Europejskiej ma u siebie system stalych cen regulowany ustawowo - i doclać tu nale$\dot{z y}$ że odpowiednie akty prawne poważnie ograniczają możliwość manipulowa- 
nia rabatami (obowiązują określone w procentach „widełki”) w relacjach wydawców $z$ dystrybutorami i księgarzami. Prekursorką była tu Francja, wprowadzając swoje słynne prawo Langa w $1981 \mathrm{r}$. W niektórych krajach natomiast (m.in. we Włoszech i Niemczech) odpowiednie ustawy przyjęto stosunkowo niedawno, już po 2000 r. Przeciwna takiej tendencji jest Komisja Europejska. Rada Konkurencji tejze Komisji dostrzega w prawie Langa i innych podobnych mu rozwiązaniach podważanie aksjomatu o wolności handlu. Ostatnio w gremiach UE przeważyło jednak stanowisko kompromisowe, dopuszczające w drodze wyjątku zachowanie systemu stałych cen książek w poszczególnych krajach ${ }^{56}$.

W Polsce zwolennicy systemu wprowadzonego przez większość dawnych członków UE uważają, że u nas istotnie uporząllkowałby on rynek (głównie przez wyeliminowanie konsygnacji), stworzyłby choć minimum szans na przetrwanie niezależnych księgarń, zagrożonych konkurencją sieci i marketów oraz ukrócił praktykę zawyżania cen przez pośredników ${ }^{57}$. Przeciwnicy na ogół po prostu optują za wolnością. Z felietonową dosadnością wyraził to np. stale publikujący w „Bibliotece Analiz” autor ukryty pod pseudonimem Pigr:

„Książka (czy to kogoś uraża, czy nie) jest takim samym towarem handlowym jak pomidor, walizka czy worek cementu. Ale czy któremuś z producentów, dajmy na to warzyw, przyszło do glowy, by drukować ceny detaliczne na pomidorze? Nie. Taki absurdalny pomysł mógł zrodzić się tylko w szacownych glowach wydawców. (...) Różnice cenowe w obrębie tego samego produktu są sprawą najzwyklejszą na świecie. Jeśli klient zamierza kupić telewizor konkretnej marki, szuka najlepszej oferty. Dokona zakupu tam, gdzie jest taniej. I prawdopodobnie wkrótce wróci, by nabyć radio. Tak samo ma się rzecz w przypadku książki. Dajmy zatem szansę sprzedawcy, by samodzielnie kreował rzeczywistość handlową wokół siebie i nie zrównujmy na siłę twórczych, przedsiębiorczych detalistów z ostatnimi miernotami, którzy mentalnie tkwią w okresie reglamentacji wszystkiego, co tylko możliwe" ${ }^{58}$.

Zamykając wątek regulacji cen dodajmy, że wypracowanie wspólnego stanowiska polskiej branży książkowej w tej kwestii wydaje się obecnie nierealne.

Zrozumiałe, że w dyskusję na temat kwestii cen oraz pojawiających się zawsze w takiej sytuacji rozważań dotyczących marż i rabatów angażują się - prócz wydawców - hurtownicy i księgarze. Problem dystrybucji stanowi przecież jedno $z$ najtrudniejszych zagadnień na polskim rynku książki.

P. Kotler zdefiniował dystrybucję jako działalność zorientowaną na osiaganie zysku, obejmującą „planowanie, realizację i kontrolę fizycznego przepływu materiałów i finalnych produktów z miejsca pochodzenia (produkcji) do miejsca ich zbycia" ${ }^{59}$. Jolanta Mazur zaznacza, że dystrybucję można kształtować na dwa sposoby: poprzez kanały dystrybucji (pośredników) oraz fizyczne dostarczanie towarów (czyli logistykę). Dystrybucja może być bezpośrednia (gdy prowadzi ją producent towaru) oraz pośrednia (gdy korzysta $z$ pośredników, którzy mogą tworzyć krótsze lub dłuższe kanały dystrybucji) ${ }^{60}$.

$Z$ zagadnień teoretycznych istotny wydaje się tu także wątek strumieni rynkowych i ich przeplywu przez kanal dystrybucji. Owe strumienie to w uprosz czeniu porządek przekazywania pewnych istotnych elementów w realiowanych kolejno operacjach: np. droga przez rynek prawa własności (ew. prawa użytkowania w systemie leasingowym) od producenta, poprzez hurtownika, sprze- 
dawcę detalicznego po nabywcę finalnego. J. Mazur zauważa, że w systemie marketingu mix rozmaite jego elementy są kształtowane poprzez oddziaływanie dwukierunkowe: strumień płynący tradycyjnie od producenta ku odbiorcy - oraz odwrotnie ${ }^{61}$.

Wyróżnia się także różne strategie dystrybucji. Trzy podstawowe to: dystrybucja intensywna (gęsta sieć dystrybutorów), selektywna (ograniczona liczba pośredników) i wyłączna (określana też niekiedy jako ekskluzywna) ${ }^{62}$.

Próbując przełożyć to na język pralityki, T. Woll podkreśla, że dystrybucja stanowi jedno $z$ najważniejszych zagadnień w działalności wydawnictw. Podaje różne metody jego rozwiązania stosowane w oficynach amerykańskich - każda $z$ nich wymaga kompetencji i elastycznego potraktowania przez osoby podejmujące decyzje. Zdaniem tego autora, najlepszym sposobem prowadzenia sprzedazy jest po prostu zatrudnienie w wydawnictwie wyspecjalizowanego personelu (przedstawicieli handlowych), który prowadził będzie sprzedaż bezpośrednią. Taki system pozwala na pełną kontrolę wydawcy nad drogą jego książek przez rynek i minimalizację związanego $z$ tym ryzyka. Jest jednak kosztowny, mogą sobie na niego pozwolić tylko firmy osiągające duże obroty. Co charakterystyczne, $\mathrm{T}$. Woll odradza jednak małym wydawnictwom korzystanie $z$ usług hurtowników, głównie dlatego że nie prowadzą oni - jego zdaniem alktywnej sprzedaż ksiązek. Ani hurtownik, ani dystrybutor nie będą pracować właśnie „Z naszymi książkami”; w sposób naturalny skoncentrują się przecież na tytułach aktualnie sprzzedających się najłatwiej ${ }^{63}$.

Inny autorytet w tej dziedzinie, J. Huenefeld, formułuje swą opinię na ten temat jeszcze ostrzej. Uważa on, że strategia rynlowa amerykańskich firm dystrybucyjnych stanowi w gruncie rzeczy „subtelną formę nieuczciwej dyskryminacji" małych wydawnictw. Aby dotrzeć ze swymi książkami do liczących się hurtowni i dużych sieci księgarskich, oficyny te zmuszone zostały do zaakceptowania ogromnych rabatów $-z$ oczywistą szkodą dla swej rentowności, a w szerszym kontekście - dla czytelników i autorów ${ }^{64}$. I Huenefeld, i Woll zalecają mniejszym podmiotom przede wszystkim sprzedaż bezpośrednią, choć Woll zdaje się nieco dystansować wobec zdecydowanej niechęci Huenefelda odnośnie dystrybutorów, nie wymieniając zresztą jego nazwiska pisze krytycznie o poglądach „pewnego cieszącego się zasłużonym szacunkiem konsultanta małych wydawców"65.

Warto pamiętać o problemach związanych z dystrybucją książek w USA, gdy analizujemy sytuację na rynku krajowym. Oczywiście, strzeżmy się przed pokusami zbyt łatwych analogii, bo przecież obaj cytowani przed chwilą autorzy krytykują hurtowników przyjmując punkt widzenia szefów małych wydawnictw - a w USA w dobie globalizacji to jednak koncerny decydują o najważniejszych sprawach książki. Trzeba też podkreślić, że na naszym rynku niewielu jest dystrybutorów w ścisłym tego słowa znaczeniu (czyli firm dostarczających książki nie tylko księgarniom, ale przede wszystkim pośredniczących między wydawcami a duzymi sieciami hurtowymi). Pewne przestrogi - zwłaszcza te przed niezbyt dużą efektywnością pracy hurtowni, ich brakiem elastyczności wobec tytułów nie będących bestsellerami - da się jednak uogólnić.

W Polsce najbardziej bolesnym (i najbardziej spektakularnym) przejawem kryzysu na rynku książki w ostatnich latach były upadki dużych i średniclı hur- 
towni (Liber, Światowid, Kwadro, Reprinty, Sezam i in.). Jak podaje Ł. Gołębiewski, tylko na przestrzeni 2000 r. wydawcy stracili z powodu zapaści w dziedzinie hurtu ok. $30 \mathrm{mln}$ złotych ${ }^{66}$. Według dziennikarza „Rzeczpospolitej”, $z$ kryzysowym wyzwaniem najgorzej radziły sobie duże hurtownie ${ }^{67}$, co oczywiście da się uzasadnić nie tylko wspomnianymi przed chwilą bankructwami, ale też kłopotami tych potentatów, którzy przetrwali (Wkra, Azymut). Zauważmy jeclnak, $\dot{z}$ upadały nie tylko duże przedsiębiorstwa. Znikły też $z$ rynku m.in. takie firmy, jak Sartorius, Porębscy, Urbańczyk i Kos, Opus, Supo. Mniejsza skala dzialalności nie stanowiła wcale gwarancji mniejszego zagrożenia bytu hurtowni.

Zapewne $Ł$. Gołębiewski ma natomiast rację twierdząc, że najgorsze chyba już minęło i „sytuacja w dystrybucji nieco się uspokoiła”. Uzasadnia to m.in. postępującym mimo wszystko procesem koncentracji, zaświadczającym poprawę kondycji największych firm, oraz znaczącym rozwojem tych niedawno jeszcze nieduzych, jak FK Jacek Olesiejuk i Wikr ${ }^{68}$.

Ów względny spokój udało się osiagnąć m.in. dlatego że wydawcy, pod wplywem zlych doświadczeń, nauczyli się radzić sobie bez hurtowników. Umiały uporać się $z$ tym problemem silne oficyny edukacyjne (MAC, Nowa Era, w pewnym sensie WSiP) oraz fachowe (PWP, CH Beck) ${ }^{69}$, ale udane próby podjęły te $\dot{z}$ niektóre mniejsze przedsiębiorstwa. Tomasz Michałowski w wywiadzie dla „Biblioteki Analiz” stwierdził, że jego Siedmioróg stara się ograniczyć do minimum współpracę z hurtowniami. Zastrzegł przy tym, iż „,koszty tak prowadzonej dystrybucji są jednak na tyle duże, że pożerają prawie cały nasz zysk"70. Sprzedaż bezpośrednia czy różne zbliżone do niej rozwiązania są zatem kosztowne nie tylko na rynku amerykańskim. Ale i tu, i tam są w sumie mniej ryzykowne - cytowane powyżej konstatacje T. Wolla można odnieść i do polskich realiów.

Co cielawe, $z$ dziedziny hurtu zdają się wycofywać także niektórzy hurtownicy. W obrotach Matrasa coraz więlkszy odsetek stanowią przychody uzyskiwane dzięki konsekwentnemu rozbudowywaniu sieci księgarskiej. Na mniejszą skalę czyni to równiez MarKa, której wiceprezes, Maria Kanior, podczas publicznego spotkania branżowego wyraziła nawet przypuszczenie, że w przyszlości hurt w obecnym kształcie stanie się zbędny ${ }^{71}$. Ofertę alternatywną w stosun$\mathrm{ku}$ do hurtowni (obejmującą magazynowanie, logistylkę, faktoring) rozwija natomiast należąca do koncernu Bertelsmanna firma Arvato Service Polska. Kusi ona nie tylko dobrymi wzorami niemieckiej solidności (to poważny argument po niedawnych i calkiem współczesnych doświadczeniach $z$ dystrybucją), ale też i cenami swych usług $^{72}$.

Tradycyjny schemat rynkowy naturalnym partnerem hurtowni czynił księgarnie. Księgarstwo polskie pogrążone jest w kryzysie, liczba placówek wciąż maleje. Jeszcze w 1999 r. w bazie Centrum Informacji o Książce było ich ponad $3000^{73}$; w końcu 2002 r., według innych szacunków, ich liczba spadła do ok. $2500^{74}$

Spada też udział księgarń w rynku - od 62,5\% w 1995 r. do 41,3\% w 2002 r. $^{75}$. To już jednak fragment uniwersalnej tendencji. Nawet w Niemczech, gdzie czytelnicy są bardzo przywiązani do dawnego modelu, odpowiedni odsetek maleje (choć wciąż jest względnie duży). Amerykanie natomiast zdecydowanie wolą zakupy w megastorach i superstorach (dwie wielkie sieci Barnes\&Noble 
i Broders) niż w księgarniach asortymentowych; po kryzysie $z$ lat dziewięćdziesiątych XX w. „zaszły dramatyczne zmiany (...) - zaginął już ślad po wielu najbardziej znanych niezależnych księgarniach"76.

Ze spraw, które na polskiej niwie księgarskiej wolno ocenić pozytywnie (choć wbrew samopoczuciu więlkszości uczestników tego fragmentu rynku) odnotujmy okrzepnięcie dwóch sieci ogólnopolskich (Empik, Matras), co Ł. (jołębiewski postrzega jako początek nieuniknionej konsolidacji. Choć nie powiodła się francuska inwestycja kreowania sieci Extrapole (wzorem znad Sekwany i Loary megastory miały działać w wielkich centrach handlowych na obrzeżach dużych miast), ale dobre wrażenie robi Traffic Club w Warszawie, stwarzając przeciwwagę dla dwóch wielkich placówek Empiku. I zauważmy jeszcze, że renoma takich księgarń niezależnych, jak warszawskiej im. Prusa, Agory z Bolesławca czy Eureki ze Świdnicy wydaje się niezagrożona.

Atternatywę i dla firm niezależnych, i dla sieci, tworzy natomiast stale rozwijająca się sprzedaż klubowa i wysyłkowa. Tu na marginesie trzeba zauważyć, że $w$ tych sprawach wciąz mamy kłopoty $z$ terminologią. Funkcjonuje $u$ nas przeciez tylko jeden klub w ścisłym tego słowa znaczeniu. To Świat Książki koncernu Bertelsmanna, gdzie prócz przywilejów są i obowiązki - członkowie są zobligowani do zakupu wyznaczonej pozycji w przypaclku niezłożenia samodzielnego zamówienia. Najpoważniejszą cllań konkurencję stwarza Klub dla Ciebie, własność firmy Weltbild. Nazwa jest myląca - w Niemczech nawet reklamowano sprzedaż internetową prowadzoną przez ten podmiot hasłami „bez klubu, bez członkostwa"ī. Podobnie jak w Klubie Książki Księgarni Krajowej (Prószyński i S-ka) czy Klubie Książki Katolickiej, kupujący nie mają wobec tych firm obowiązków typowych dla klubów ${ }^{78}$.

Niezależnie jednak od tych uwag, sprzedaż klubowa (tu już bez zastrzeżen posłużymy się pojęciem powszechnie u nas stosowanym) i wysyłkowa rozwija się: w 1998 r. stanowiła 24\% ogólnych przychodów ze sprzedaży książek w Polsce, w 2002 r. - już 30\% ${ }^{79}$. Jak zauważy w związku z tym B. Klukowski, być może pozyskiwanie nowych nabywców dotychczas niekupujących książek oka$\dot{z e}$ się już niemożliwe ${ }^{80}$. W takiej sytuacji, jeśli utrzyma się tendencja wzrostowa tego typu sprzedaży, to dokonywać się będzie kosztem tradycyjnych księgarni. Choć na marginesie warto zauważyć, że specjalizujące się w sprzedaży wysy\}kowej wydawnictwo Readers Digest zdecyclowało się niedawno część swej oferty skierować właśnie do księgarń.

Duże emocje buclziła swego czasu sprzedaż książek w supermarketach. Księgarze burzyli się przeciwko konkurencji walczącej przy pomocy niskich cen detalicznych, hurtownicy narzekali na twarde warunki rozliczeń (długie terminy płatności), wszyscy dostawcy - na wymuszanie wysokich rabatów (i przynajmniej część tych uwag pozostaje aktualna). Istotne okazały się też normy i nawyki, słusznie kojarzone z kulturą książki. Andrzej Nowakowski pisal w 1999 r. w swym felietonie w „Notesie Wydawniczym”:

„Jeśli ktoś mi dzisiaj powie, że książka oznacza kulturę, tradycję, wartość i Bóg wie co tam jeszcze (..), to spieszę donieść, że w sieci hipermarkrtów „Hit” książki są sprzedlawane na wagę. Tak! Właśnie nabyłem w jednym $z$ nich 15 dekagramów Janusza Andermana za 75 groszy, 5 zł za kilogram. Krótko mówiąc, w sensie jak najbardziej dosłownym położyłem na szalę i zważyłem wyda- 
ny w 1990 r. tomik 'Brak tchu. Kraj świata'. W wózku miałem trochę serka fromage, kilka porów na sałatkę, kawałek kiełbasy, banany, śledzie marynowane (bo lubię), jajka i... Andermana. Anderman został zważony tuż po bananach, a przed porami. Kasjerce powieka nie drgnęła, a ja miałem poczucie, że mój świat się nieznacznie, ale jednak zmienia. I tylko to zażenowanie, ze Anderman jest tańszy niż trzy kurze jaja! Pomyśleć: gdyby tak dorzucić do książki 300\% podatku VAT, to może nie będzie aż taki wstyd kupić po kilogramie Miłosza, Szymborskiej i Twardowskiego" ${ }^{81}$.

Dziś także w niektórych supermarketach praktykuje się akcje promocyjne typu „Książka na kilogramy” czy „Książka za złotówkę”, a dostawcy twierdzą, że nie mają wpływu na przedsięwzięcia handlowców Tesco czy Carrefoura. I choć wydawcom sprzedlającym swe publikacje w tych placówkach księgarze zarzucają brak odpowiedzialności ${ }^{82}$, to jednak uczestnicy rynku przywykli już do obecności książki w marketach. Z właściwą sobie swadą tak skomentował to Pigr:

„Wolny rynek uregulował już więlsszość kwestii handlowych związanych $z$ hipermarketami; lepsi zarabiaja, słabszym pozostaje powszechne i modne supernarzekanie na supermarkety" ${ }^{83}$.

Handel książką w super-i hipermarketach nie jest oczywiście polskim wynalazkiem. Nie osiągnął te $\dot{z}$ u nas imponujących finansowo rozmiarów; stanowi 78\% ogólnej sprzedaży na rynku wydlawniczym. Ale, jak zauważa Ł. Gołębiewski, gdyby sieci detaliczne i sieci marketów połączyć w jedną kategorię analityczną, to w pierwszej piątce najważniejszych sprzedawców znalazłyby się takie firmy jak Auchan, Tesco (ta firma ma najwięcej punktów sprzedaży książek spośród wszystkich marketów) i Carrefour, zaraz za Empikiem i Matrasem ${ }^{84}$.

Markety - zgodnie $z$ filozofią handlu w takich placówkach - przyjmują do sprzedaży publikacje o szybkiej rotacji: bestsellery $z$ dziedziny literatury pięknej, książki dla dzieci, albumy, poradniki, w sezonie - przewodniki. Klientom oferują ceny niższe o ok. 10-15\% niż w księgarniach. Partnerami poszczególnych sieci są bądź bezpośrednio wydawcy, bądź niektórzy hurtownicy (wyraźnie dominuje w tej dziedzinie FK Jacek Olesiejuk) ${ }^{85}$.

Wspomnieć warto jeszcze o sprzedaży internetowej książek. Kilka lat temu wiązano $z$ nią duże nadzieje. Na świecie przeżywa ona jednak kryzys, a wedle badań amerykańskiej firmy Jupiter Communications w dającej się przewidzieć przyszłości nie przelkroczy 15\% ogólnych obrotów osiąganych dzięki zakupom odbiorcy finalnego. Chociaż aż $70 \%$ osób kupujących w internecie zamawia właśnie książki, T. Woll przestrzega wydawców przed wiązaniem $z$ tym medium nadmiernych oczekiwań i podkreśla, że to tylko „pomocnicza forma sprzedaży"

$\mathrm{Na}$ świecie szeroko znana jest księgarnia internetowa Amazon.com. W Polsce samotnym liderem pozostał Merlin.pl; Empik.com, po zmianie właściciela (przejął go Elektrim), w 2001 r. zawiesil działalność. Ogólne obroty ze sprzedaży w sieci (poza Merlinem i średniej wielkości firmą Vivid.pl) są u nas bardzo rozproszone i nie zapewniają poważniejszych zysków ${ }^{87}$.

Nie tylko w dziedzinie sprzedaży internetowej dzieje się tak czasem bez związku z cechami oferowanych produktów. Specjaliści przestrzegają nawet, że „w warunkach współczesnego rynku dostarczenie właściwego produktu po 
odpowiadlającej nabywcom cenie i udostępnienie go im może nie gwarantować dokonania sprzedaży" ${ }^{88}$. Opinię tę potwierdza potoczna obserwacja praktyka magazyniera w jednej $z$ polskich hurtowni książek: „Dziwi mnie fakt, $\dot{z} e$ wcale nienajlepsze podręczniki cieszą się tak duzym popytem" ${ }^{89}$. Kluczowe zagadnienie ma przecież kwestia promocji.

J. Mazur olkreśla promocję jako „podejmowanie przez dostawcę różnorodnych działań mających na celu skłonienie odbiorcy do wyboru produktu oferowanego przez clostawcę po określonej cenie w danym miejscu i czasie" ${ }^{90}$. Zastrzeżmy, że na rynku książki (i nie tylko tu) najczęściej główną rolę w kwestii promocji gra producent - choć oczywiście cenny jest udział (współudzial) i pośrednika hur towego, i sprzedawcy detalicznego.

A. Sznajder pisze natomiast:

(...) „promocja to oddziaływanie na odbiorców produktów przedsiębiorstwa, pole-gające na przekazywaniu informacji, które mają w odpowiednim stopniu zwięk-szyć ich wiedzę na temat towarów firmy - w celu zdobycia ich preferencji na rynku. Jest to więc taki sposób komunikowania się przedsiębiorstwa $z$ otoczeniem, który w efekcie ma się przyczynić do zwięlkszenia popytu nabywców na towary sprzedawane przez daną firmę"11.

I tu jednak nie obejdzie się bez zastrzeżeń. Po pierwsze, promocja nie polega wyłącznie na oddziaływaniu na odbiorców produktów. Bardzo często jej obiektem są pośrednicy rynlkowi na drodze produktu do odbiorcy końcowego, często także - dziennikarze. T. Woll powie w pewnym kontekście (już w odniesieniu do spraw wydlawniczych), ze chodzi po prostu o to, aby „powiadomić branżę o nowej książce" ${ }^{92}$. Po drugie, specyficzne są informacje przekazywane w ramach promocji, bo eksponują wyłącznie zalety (ew. cechy „neutralne”) produktu, promujący wcale nie zabiega o informację pełną (czyli uwzględniającą też mankamenty), co mogłoby sugerować stwierdzenie autora. Po trzecie, podobne zastrzeżenia dotyczą również wiedzy nabywców (i potencjalnych nabywców) produktu.

Oboje autorów - J. Mazur, A. Sznajder - dostrzega zresztą te kwestie, czego clowodzą dalsze partie cytowanych haseł z Encyklopedii biznesu. Sprawa polega więc tylko na pewnych słowach nie dość fortunnie użytych w proponowanych definicjach.

W nawiązaniu do pojęcia marketingu mix używa się również terminu promotion mix. Poszczególne elementy tak pojętej promocji powinny uzupelniać się nawzajem. Kotler wyróżnia: reklamę, promocję sprzedaży, marketing bezpośredni, public relations i publicity oraz sprzedaż osobistą ${ }^{93}$.

Autor przestrzega twórców reklamy, że choć stwarza ona szansę na ciekawe zaprezentowanie firmy, to jednak „przesadna wyrazistość przekazu” może mieć negatywny wpływ na odbiorcę i w rezultacie odwrócić jego uwagę od spraw dla nadlawcy zasadniczych. Zauważa też, że reklama jest „monologiem, a nie dialogiem $z$ publicznością", zatem skuteczność owego monologu stanowi niemal zawsze niewiadomą. $Z$ drugiej strony jednak już sama obecność reklamy produktu w środkach masowego przekazu może mieć korzystny wpływ na sprzedaż, a konsumenci - dodajmy: często zapewne podświadomie - lączą intensywność kampanii reklamowej $z$ oceną jakości towaru ${ }^{94}$. J. Huenefeld, nie wątpiąc w zasadność relklamowania książek, przypomina też jednak, że nawet na rynku 
amerykańskim zclecydowana więlkszość ukazujących się tytułów nie ma szans na zaistnienie w żarlnym przekazie reklamowym ${ }^{95}$.

W kwestii promocji sprzedazy P. Kotler twierdzi, że choć jej komponenty (np. konkursy, kupony rabatowe, programy lojalnościowe) różnią się od siebie, to jednak łączy je killka cech charakterystycznych, m. in. „wyraźne zaproszenie do natychmiastowej sprzedazy". To narzędzie promotion mix może być użyte do lepszego zaakcentowania oferty pewnego procluktu oraz do zahamowania spadku sprzedaży towaru, który swój najlepszy czas rynkowy ma już poza sobą. Promocja sprzedaży jest jednak $z$ założenia doraźna - i podmioty rynkowe powinny $z$ niej korzystać ostrożnie. Ciągłe przeceny i ulgi mogą przecież wpływać niekorzystnie na postrzeganie produktu i jego producenta przez nabywców ${ }^{96}$.

Marketing bezpośredni polega na clotarciu producenta do odbiorcy finalnego w celu skłonienia go do zakupu czy złożenia zamówienia (telemark ting, poczta elektroniczna) ${ }^{97}$. Według P. Kotlera ten instrument promocji mix ma charakter niepubliczny, gdyż „kierowany jest zazwyczaj do określonej osoby i nie dociera do innych osób" ${ }^{98}$. Wydaje się, że to stwierdzenie nie wytrzymało jednak próby czasu. Wydawcy np. wysyłają e-maile tej samej treści, informujące o swych nowościach (oczywiście wraz z ofertą złożenia zamówienia) wielu osobom równocześnie, a ich baza adresów mailowych ma, rzecz jasna, nieprzypaclkowy charakter. W stwierdzeniu Kotlera sformulowanie: określona osoba należałoby zamienić zatem na: określona grupa osób.

T. Woll uważa, że praktykowanie marketingu bezpośredniego na rynku wydawniczym jest trudne, ale, gdy jest prawidłowe, może bardzo korzystnie wpływać na sprzedaż. Co charakterystyczne, jako jedną z najważniejszych zalet tego instrumentu wymienia możliwość ominięcia dystrybutorów ${ }^{99}$.

Zagadnienia public relations są dziś clość modne, choć specjaliści zwracają uwagę, że dochodzi w związku z tym niekiedy do mieszania pojęć - w Polsce np. myli się często funkcje PR-owca i rzecznika prasowego. Wedlug dokumentu Amerykańskiego Stowarzyszenia Public Relations, PR polega na zabiegach firmy „o zdobycie poparcia ze strony publiczności (grup społeczeństwa)"100.

Zdaniem A. Sznajclera prowaclzone przez przedsiębiorstwo działania ''R są właściwie autonomiczne wobec poszczególnych jego produktów. Powinno się natomiast realizować je najbardziej równomiernie spośród wszystkich form promocji ${ }^{101}$. Adresatami są oczywiście nabywcy końcowi i pośrednicy, w znaczenie większym stopniu niż w innych przypadkach - media, ale o swoistej oryginalności PR clecyduje też i to, iż pewna część przedsięwzięć może być skierowana ku pracownikom zatrudnionym w firmie prowadzącej działania promocyjne $^{102}$.

Specyfika PR w ruchu wyclawniczym w dziedzinie kontaktów z dziennikarzami mogłaby chyba polegać m.in. na swoistym pobratymstwie zawodowców słowa drukowanego (czy slowa publicznego - w przyjadku telewizji i radia). O tym, że mimo wszystko sytuacja w oficynach nie jest pocl tym względem aż tak bardzo oryginalna świadczyć może jednak cykl popularyzatorskich tekstów Jakuba Frołowa w „Notesie Wyclawniczym” - racly i spostrzeżenia tam zawarte dadzą się odnieść do uwag specjalisty PR pracującego w innej branży (Grzegorz Kopacz dzieli się doświadczeniami ze swych kontaktów z prasą) ${ }^{103}$.

$\mathrm{Z}$ innego artykułu J. Frołowa wysnuć wolno wniosek, że w wielu polskich wydawnictwach promocja prowadzona jest nieprofesjonalnie, często bez skru- 
pulatnych planów finansowych, bez uwzględnienia zewnętrznych i wewnętrznych kontelzstów, bez wyznaczenia celów strategicznych. W tekście jednak zostały równiez podlane przykłady pozytywne (m.in. wydawnictwa Langenscheidt Polska, Rebis, Świat Książki) ${ }^{104}$. Być może więc ogólna sytuacja w tej dziedzinie zmierzać bęclzie ku lepszemu.

Dbałość o promocję i poprawa jej jakości w poszczególnych oficynach są chyba po prostu nieuniknione wobec twardych realiów rynku. Omawiana tu domena przecież może być także dziedziną rywalizacji - A. Sznajcler wiclzi w niej „pozacenową formę konkurencji” ${ }^{105}$. Perspektywy sukcesu, ale te $\dot{z}$ i po prostu przetrwania, mają przede wszystkim te oficyny, które potrafią korzystnie ksztaltować własny wizerunek i skutecznie prezentować swą ofertę.

Sprzedaż osobista potocznie nazywana jest akwizycją. Realizuje się ją także $\mathrm{w}$ sieciach door to door: Jej cel stanowi „komunikowanie się sprzedawcy z potencjalnymi nabywcami w celu dokonywania prezentacji i sprzedazy oferty oraz utrzymywania dobrych osobistych relacji” ${ }^{106}$. Jako istotne cechy tej formy promocji P. Kotler wymienia osobistą kontrontację (ułatwia ona elastyczność sprzedawcy wobec oczelkiwań odbiorcy), utrzymywanie znajomości (dobra znajomość obu stron, dlbałość o klienta, jego lojalność wobec sprzedawcy) oraz odpowiedź (potencjalny nabywca pod wpływem skutecznego akwizytora czuje się niejako zmuszony do zapoznania się $z$ ofertą i udzielenia odpowiedzi) ${ }^{107}$.

$\mathrm{Na}$ polskim rynku książki sprzedaż osobista prowadzona jest przede wszystkim przez przedstawicieli handlowych wydawnictw i hurtowni. Są to często firmy jednoosobowe (tzw. samozatrudnienie) docierające do końcowego klienta (np. do bibliotek). Szczególnie ważna okazała się sprzedaż osobista publikacji na rynku edukacyjnym po 1999 r. w związku z reformą oświaty i ostrą rywalizacją wydawców o względy nauczycieli - Ł. Gołębiewski ocenia, że akwizytorzy realizują obecnie ȧ் $1 / 3$ obrotów książkami na rynku szkolnym ${ }^{108}$. Rodzi to pretensje, a nawet przeciwdziałania księgarzy, próbujących z kolei wywierać naciski na resort oświaty.

Powodzenie wszelkich przedsięwzięć marketingowych zależy od prawidłowego rozpoznania rynku. T. Woll przytacza w swej ksiązce wyniki interesujących badań preferencji nabywców książek w USA. W 1996 r. 44\% clorosłych respondentów stwierdziło, że clecyzję o zakupie podejmuje kierując się przede wszystkim tematyką publikacji, $24 \%$ - reputacją autora. Cena natomiast była istotna dla zaledwie $2 \%$ ankietowanych, okładka - również, obecność tytułu na listach bestsellerów - dla mniej niż $1 \%$ tej próby ${ }^{109}$.

Wedle innych badań z 1997 r., również cytowanych przez T. Wolla, w USA 59\% nabywców planuje zakup książki z pewnym wyprzedzeniem, $40 \%$ kupuje ją pod wpływem impulsu. $63 \%$ uważa wpływ list bestsellerów na decyzje o zakupach za mało istotny, tylko $23 \%$ za ważną w tym kontekście uznaje okładkę. Aż $66 \%$ respondentów powiedziało natomiast, że przywiązuje wagę do tekstów na skrzydełkach obwoluty i na czwartej stronie okładki ${ }^{110}$.

T. Woll interpretuje owe wyniki jednoznacznie. Wydawcy i księgarze powinni orientować się w preferencjach tematycznych publiczności i drukować przede wszystkim dzieła renomowanych twórców. Przy okazji autor stwierdza chyba nie bez złośliwości, że „wszystkie te tłumy ludzi (...) w redakcjach, działach sprzedaży i marketingu wydawnictw - poświęcają mnóstwo czasu na sprawy 
mające marginalny wpływ na podejmowane przez czytelników decyzje o zaku pie" 111 .

Zauważmy jednak, że w ogóle badania dotyczące czytania i zakujów książek wymagają dość ostrożnej interpretacji. W tej dziedzinie szczególnie ważna jest znana reguła, wedlug której respondenci najczęściej pragną dobrze wypaść w oczach ankieterów. Można zatem przypuszczać, iż część $z$ nich wyolbrzymia swoje zainteresowanie książkami ${ }^{112}$. Ma tė tendencję do werbalnego lekcewazenia wpływu na wlasne wybory tych aspektów, które wydają się zbyt popularne, po prostu gminne. Nawet wyniki badań prowadzonych przez tak szacowne instytucje, jak Amerykanskie Stowarzyszenie Księgarzy, należy więc przyjmować chyba $z$ nieco więlkszym dystansem, niż np. cytowany T. Woll. Co oczywiście nie znaczy, zeby en bloc odmawiać im wiarygodności.

Uwzględniając różne zastrzeżenia stwierdzimy, że badania społecznego zasięgu książki w naszym kraju, systematycznie prowadzone przez $\mathrm{IKiC}_{2} \mathrm{BN}$, słusznie uważa się za na ogół miarodajne. Dowodzą one m.in., iż nabywcy indywidualni są - zapewne z konieczności - pragmatyczni. Zdaniem Katarzyny Wolff w 2002 r. „o kupnie książki decydowała głównie konieczność, przyjemność rzadko dawała o sobie znać. Decyzje podejmowano raczej rozważnie, o rozrzutności nie było mowy, a i tak niewielu mogło sobie na tę odrobinę luksusu pozwolić. A więc: książka dla bogaczy? Jeszcze nie, ale z pewnością nie dla każdego" $" 113$.

W próbie uwzględnionej przez M. Switałę (jak już wspomniano: niereprezentatywnej, ale zaznaczmy, że wylkazującej też wyraźną nadreprezentację osób zainteresowanych ksiązką) 32\% respondentów akceptuje cenę książki do $20 \mathrm{zk}$ i równiez $32 \%$ do $50 \mathrm{zl}$, a zaledwie $7 \%$ - powyżej $200 \mathrm{zł}^{114}$. Widać zatem, że dla polskiego odbiorcy - rzekomo w przeciwieństwie do amerykańskiego - cena publikacji odgrywa ważną rolę, $z$ reguly wpływając negatywnie na zasięg zalsupów.

By nie powracać do wątków wcześniej omówionych, przypomnijmy tylko, ze cena jest oczywiście jednym $z$ elementów marketingu mix. Bez uwzględnienia wzajemnej współzależności właśnie ceny oraz cech produktu, aspektów dustrybucji czy promocji, trudno o sukces na rynku książki. „Jedynie firmy zdające sobie sprawę $z$ oczekiwań klienta, zaspokajające jego pragnienia i potrzeby, stworzą ofertę akceptowaną przez nabywcę i zaskarbią sobie jego przychylność" - stwierdził M. Świtała ${ }^{115}$.

Kladąc nacisk na atrakcyjność produktu dla nabywcy, wypowiedział się on w podobnym duchu jak A. Baverstock. Stwierclziła ona: „właściwy produkt to ten, którego klient chce albo którego zechce - i będzie gotów zan zapłacić - gdy tylko zostanie poinformowany o jego istnieniu" 116 .

Powyższe stwierdzenia $z$ punktu widzenia producenta wydają się oczywiste. A jednak, gdy uwzględnimy różne aspekty $z$ domeny marketingu mix, znowu nie unikniemy zastrzezeń. Podkreślić tu należy jeszcze raz znaczenie promocji, ale przecież nie tylko jej - a przynajmniej nie tylko w kontekście dotarcia do odbiorcy końcowego. Otóż P. Kotler zauważył, że amerykańskie markety są w stanie przyjąc zaledwie $10 \%$ towarów oferowanych przez producentów ${ }^{117}$. Porady J. Huenefelda i T. Woola udzielane małym wydawnictwom - a więc tym $z$ nieporównywalnie mniejszą siłą przebicia niż potężni konkurenci korporacyjni - 
koncentrują się m.in. na problemie przebrnięcia (czasem ominięcia) fazy pośrednictwa w drodze ku etapowi sprzedazy detalicznej. Kto wie, czy na dziś i na jutro jedną $z$ najważniejszych nie pozostaje kwestia przekonania dystrybutorów przez wydawcę, że warto zajmować się jego książkami - albo tak skutecznego zorganizowania sprzedaży bezpośredniej, by móc pominąć ten problem. Jeśli oficyna nie upora się z tym wyzwaniem (obojętne, czy w pierwszym, czy w drugim wariancie), to właściwie - trochę wbrew przywołanemu we wstępnych partiach tekstu Drukerowi - o sukcesie czy porażce wyclawcy naprawdę zadecyduje nie czytelnik, lecz dystrybutor (lub system dystrybucji w wydawnictwie).

Rynek książki nawet w Stanach Zjednoczonych uchodzi za bardzo trudny. T. Woll podkreśla, że przeciętne zyski w branży wydawniczej są $w$,najlepszym przypadku (!) nieduże - chyba że komuś zdarzy się ten luksus, że w jakimś roku wprowadzi na rynek bestseller". Ostrzega też, że stosunkowo łatwo wejść na ów rynek, ale niezwykle trudno utrzymać się na nim ${ }^{118}$. J. Huenefeld zauważa nawet sarkastycznie, że „wydawcy książek zgarniają dwukrotnie mniej dochodu narodowego niz złodzieje sklepowi; $z$ handlarzami narkotyków nie wytrzymują żadnego porównania"119.

W Polsce wspomniane przez J. Huenefelda proporcje kształtują się zapewne jeszcze mniej korzystnie dla wydawców, a jalkość amerykańskiego rynku książki słusznie uchodzi za nieosiągalną ${ }^{120}$ - i to nawet wówczas, gdy uwzględnimy wstrząsy, jakie przeżyl ów rynek w latach dziewięćdziesiątych ubiegłego stulecia. Stałe i powszechne w naszej branży narzekanie męczy już niekiedy nawet doświadczonych edytorów czy dystrybutorów ${ }^{121}$. Ale obiektywnych uzasadnień złego samopoczucia uczestników rynku wymienić można wiele. Prócz zasygnalizowanych powyżej wspomnijmy sprawę nie zawsze zrozumialą dla wyclawców zachodnich - kwestię rzetelnego regulowania należności, czyli elementarnego bezpieczeństwa finansowego w kontaktach $z$ partnerami biznesowymi.

Tym bardziej cieszą optymistyczne spostrzeżenia fachowców. Marek Jaworski w „Bibliotece Analiz” bynajmniej nie lekceważy zagrożeń, takich jak stagnacja sprzedaży i spadek rentowności dużych wydawnictw. Po przestudiowaniu sprawozdań finansowych ( $\mathrm{z}$ lat 1998-2002) kilkudziesięciu ważnych oficyn podkreśla jednak, że nastąpiła racjonalizacja zarządzania majątkiem obrotowym. W sumie - zdaniem Jaworskiego - większość znaczących wydawnictw to bardzo bezpieczne podmioty, atrakcyjne dla kredytodawców ${ }^{122}$.

Diagnozę tę potwierdzają również niektóre wypowiedzi alktywnych uczestników rynku - np. Dorota Murawska, jako przedstawicielka Pearson Education w Europie Środkowowschodniej, uznała rynek polski - z perspektywy wielkiego koncernu edukacyjnego - i za bardzo obiecujący ${ }^{123}$. Redakcja „Pulsu Biznesu” w swym słynnym konkursie na najbardziej dynamiczne male i średnie przedsiębiorstwa (edycja 2003) uhonorowała m.in. Wydawnictwo Szkolne PWN, Forum, Helion, MAC Edukacja, Wilgę oraz Firmę Księgarską Serwis ${ }^{124}$. Ł. Gołębiewski w jednym ze swych aktualnych raportów stwierdzil, że menedżerowie więlkszości oficyn nauczyli się radzić sobie $z$ recesją, zatem jej skutki w ich firmach w $2002 \mathrm{r}$. były lagodne ${ }^{125}$.

Pesymistyczne i - czasem formułowane im na przekór - optymistyczne opinie na temat sytuacji na polskim rynku książki potwierdzają (pośrednio i bez- 
pośrednio) znaczenie marketingu w poczynaniach firm wydawniczych, hurtowych, księgarskich. Zapewne wiele tu jeszcze do zrobienia - wręcz irytująca wydaje się np. częsta tendencja do oszczędzania na reklamie czy public relations, choć przeciez renomowany autor podstawowego opracowania napisał na ten temat, że $z$ większanie wydatków na działania marketingowe $z$ reguły owocuje wzrostem udziałów w rynku ${ }^{126}$. Jak natomiast zauważa M. Jaworski w swej cytowanej już analizie, wyclawców - wobec słabnącego popytu - czeka zapewne jeszcze mocniej odczuwane zaostrzenie konkurencji, także kosztem dalszego obniżania rentowności ich firm ${ }^{127}$.

W dyskusji branżowej podczas 13. Targów „Edukacja” Ł. Gołębiewski stwierdził, że „coraz większą rolę będą odgrywaly zmasowane działania marketingowo - promocyjne. Nie chcę przez to powiedzieć, że musi przegrywać jakość podręcznika, autorskie programy itd., ale po względnym wyrównaniu się poziomu merytorycznego i edytorskiego większości oferowanych książek zwyciężać bęclzie prawie zawsze ta, która otrzymała największe wsparcie w zakresie techniki sprzedaży" (...) ${ }^{128}$.

Dyskusja koncentrowała się wokół problemów hurtu edukacyjnego, ale przytoczony fragment wypowiedzi właściciela „Biblioteki Analiz” z pewnością można uogólnić jako odnoszący się clo realiów całości polskiego rynku książki. W niełatwej rywalizacji wygrają zapewne ci, którzy będą sprawnie operować m.in. narzędziami marketingu mix.

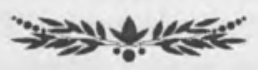

\section{Przypisy:}

1 P. Kotler, Marketing. Analiza, planowanie, wdrazanie i kontrola, Warszawa 2004; wspomnieć tu również warto, zawierającą wiele cennych uwag i spostrzeżeń, pullicystyczną książkę tegoż autora: Marketing od $A$ do $Z$, Warszawa 2004.

${ }^{2}$ J. Włodarczyk, Marketing wydawniczy $8 p$., Kraków [br. d. wyd.]

${ }^{3}$ M. Świtała, Zachowania konsumentów i marketing na rynku ksiąziki, Warszawa 2003

${ }^{4}$ M. Zając, Promocja ksiąziki dziecięcej. Podręcznik akademicki, Warszawa 2000.

${ }^{5}$ J. Huenefeld, Zarzadzanie wydawnictwem w warunkach gospodarki rynkowej, Kraków 1994; A. Baverstock, Marketing w wydawnictwie. Fantazja czy rzeczywistość?, Kraków 1996; T. Wool, Jak osiągnąć zysk w wydawnictwie [br. daty i miejsca wyd.]; Jak osiągnąc sukces w ksieggarstwie [br. daty i miejsca wyd.].

${ }^{6}$ E. Gołębiewski, Rynek książki w Polsce 2003, t. 1-2, Warszawa 2003. Wspomnieć tu trzeba także poprzednie prace tego autora pod podobnymi tytulami, ukazujące się regularnie od $1998 \mathrm{r}$.

${ }^{7}$ Najnowsza pozycja na ten temat: G. Straus, K. Wolff, Sienkiewicz, Mickiewicz, Biblia, harlequiny. Spoleczny zasiegg ksiązki w Polsce w 2000 roku, Warszawa 2002.

${ }^{8}$ B. Klukowski, Ksiązka w świecie wspólczesnym, Warszawa 2003.

${ }^{9}$ W. Wilczyński, Rynek, w: Encyklopedia biznesu, (red.), W. Pomykało, Warszawa 1995 , t. 2, s. 829 . 
${ }^{10}$ P. Kotler, Marketing. Analiza..., s. 6; tenże, Marketing od A do Z..., s. 40.

${ }^{1}$ Tenże, Marketing od $A$ do $Z$..., s. 180.

${ }^{12}$ Cyt. za: Tenże, Marketing..., s. 1.

${ }^{13}$ A. Sznajder, Marketing, w: Encyklopedia biznesu..., t. 1, s. 475.

${ }^{14}$ A. Baverstock, op. cit., s. 24.

${ }^{15}$ P. Kotler, Marketing..., s. 1 i 6.

${ }^{16} \mathrm{~J}$. Huenefeld, op. cit., s. 293; por. uwagi na temat różnych koncepcji marketingu w: J. Wojciechowski, Marketing w bibliotece, Warszawa 1993, s. 12-16.

${ }^{17}$ A. Sznajder, op. cit., s. 476.

${ }^{18}$ Ibidem, s. 477.

${ }^{19}$ P. Kotler, Marketing..., s. 89.

${ }^{20} \mathrm{Za:}$ jw.

${ }^{21} \mathrm{~W}$ Polsce jej zwolennikiem i propagatorem jest m.in. J. Włodarczyk; por. wstepp jego autorstwa do A. Baverstock, op. cit., s. 10.

${ }^{22}$ Wg. P. Kotler, Marketing od A...., s. 97-98 oraz tegoż: Marketing. Analiza..., s. 101, przyp. 2.

${ }^{23}$ Tenże, Marketing. Analiza..., s. 89.

${ }^{24}$ Ibidem, s. 90 i 400.

${ }^{25}$ A. Baverstock, op. cit., s. 19.

${ }^{26}$ M. Świtała, op. cit., s. 87; por. M. Zając, op. cit., s. 125 i nn.

${ }^{27}$ Ł. Golębiewski, Polskie Wydawnictwa Profesjonalne. Rozmowa z Whodzimierzen Albinem, „Biblioteka Analiz”, nr 6, 2001, s. 4.

${ }^{28}$ Tenże, Rynek książi... 2003, t. 1, s. 146-147 i 248-250.

${ }^{29}$ (JH), Rynek publikacji fachowych. Elektroniczny Beck, „Biblioteka Analiz”, nr 15, 2003, s. 14 .

${ }^{30}$ Ł. Gołęloiewski, Rynek ksiązki..., t. 1, s. 205.

${ }^{31}$ M. Tobera, Ikar dla Czytelnika, „Notes Wydawniczy”, nr 10, 1998, s. 11.

${ }^{32}$ P. Weidhaas, Tylko ustugi, „Notes Wydawniczy”, nr 9, 1996, s. 7-9.

${ }^{33}$ Zob. M. Bialecka, Decyzje szybkie, decyzje mądre, "Notes Wydawniczy”, nr 1, 2001, s. 4-6; M. Szymańska, Oby trwaly, tamże, s. 7-10. B. Klukowski, Frankfurt 2003 od kuchni i od salonów, „Notes Wydawniczy”, nr 11, 2003, s. 26-28.

${ }^{34}$ N. Gowin, Sukces pomimo usterek, „Notes Wydawniczy”, nr 11, 2003, s. 24-25; por. uwagi J. Wlodarczyka na temat targów książki postrzeganych z punktı widzenia specjalisty w dziedzinie marketingu, tenże, op. cit., s. 78-82.

${ }^{35}$ t. Gołębiewski, Bitwa o autorów, „Rzeczpospolita”, nr 226 (25-26 września), 2004, s. A1 i A14.

${ }^{36}$ A. Sznajder, op. cit., s. 479.

${ }^{37}$ Ibidem.

${ }^{38} \mathrm{~J}$. Wlodarczyk, op. cit., s. 33; por. uwagi M. Zająca, op. cit., s. 136-138.

${ }^{39}$ Z. Wiankowska-ładyka, Porządek książki, „Wydawca”, nr 1, 1998.

${ }^{40} \mathrm{~J}$. Włodarczyk, op. cit., s. 33.

${ }^{41}$ M. Jedrczak, Towar i opakowanie, „Notes Wydawniczy”, nr 10, 1993, s. 25. Autor, doświadczony grafik książkowy, zapewne nie do końca zgodziłby się z cytowanym powyżej J. Włodarczykiem. Zdaniem M. Jędrczaka, reklamowa funkcja okładki bywa przeceniana.

${ }^{42}$ B. Klukowski, op. cit., s. 70-71; por. T. Nowak, Skarb nierozpoznany, czyli cechy ksiązki jako produktu, „Notes Wydawniczy”, nr 10, 2003, s. 32. 
${ }^{43}$ A. Sznajder, op. cit., s. 480.

${ }^{44} \mathrm{~J}$. Whodarczyk, op. cit., s. 19.

${ }^{45}$ A. Sznajder, op. cit., s. $480-481$.

${ }^{46}$ P. Kotler, Marketing..., s. 341.

${ }^{47} \mathrm{~J}$. Whodarczyk, op. cit., s. 19.

${ }^{48}$ P. Kotler, Marketing od $A$..., s. 145.

${ }^{49}$ Zob. K. Wolff, Stereotyp a rzeczywistość, czyli indywidualni nabywcy ksiązek 2002, „Notes Wydawniczy”, n1 6, 2003, s. 33-34.

${ }^{50}$ A. Sznajder, op. cit., s. 481-482.

${ }^{51}$ J. Włodarczyk, op. cit., s. 26.

${ }^{52}$ Ł. Golębiewski, Jak zarobić na obniżce cen, „Rzeczpospolita”, nr 139 (16 czerwca), 2004, s. A11.

${ }^{53}$ Prawa Langa u nas nie chcemy, „Biblioteka Analiz”, nr 18, 2003, s. 10-11.

${ }^{54} \mathrm{G}$. Boguta opinię taką wyrazil m.in. 9 czerwca 1998 r. podczas dyskusji branżowej, która odbyla się w siedzibie PWN. Wzięli w niej udzial zaproszeni przedstawiciele wydawnictw, hurtowni i księgarń. Autor tego tekstu był obecny na sali jako uczestnik debaty oraz sprawozdawca czasopisma „Notes Wydawniczy”.

${ }^{55}$ P. Kotler, Marketing. Analiza..., s. 464.

${ }^{56}$ P. Marciszuk, Federation of European Publishers. Wątek stalych cen, „Biblioteka Analiz", nr 12, 2004, s. 22-23; Ustawa Langa. Rys historyczny, Wiadomości Księgarskie 2004, nr 2, s. 17-34; E. Szydłowska, O ustawie Langa i nie tylko. Notatki z pewnego seminarium, „Notes Wydawniczy”, nr 4, 2004, s. 24-26.

${ }^{57}$ Prawa Langa u nas nie chcemy, s. 10-12.

${ }^{58}$ (Pigr), Trójkąt Bernnudzki w oceanie ksiązek, „Biblioteka Analiz”, nr 16, 2003 , s. $10-11$.

${ }^{59}$ P. Kotler, Marketing. Analiza..., s. 536.

${ }^{60}$ J. Mazur, Dystrybucja, w: Encyklopedia biznesu, t. 1, Warszawa 1995, s. 216.

${ }^{61}$ Ibidem, s. 217.

${ }^{62}$ A. Sznajder, op. cit., s. 484.

${ }^{63}$ T. Woll, op. cit., s. 191-196; por. ibidem, s. 24 oraz J. Huenefeld, op. cit., s. 21 i 373.

${ }^{64} \mathrm{~J}$. Huenefeld, op. cit., s. 22-23.

${ }^{65}$ T. Woll, op. cit., s. 198.

${ }^{66}$ Ł. Gołębiewski, Rynek książki... 2001, s. 297. W prasie branżowej można czasem spotkać niezloyt zawoalowane sugestie, ze nie wszystkie spośród bankructw hurtowni były przeprowadzone uczciwie; zob. A. Nagraba, Swiat Kiepskich, "Notes Wydawniczy”, nr 9, 2001, s. 10; P. Dobrołęcki, R. Mendruń, Po pierwsze uczciwość. Rozmowa z Jackiem Marciniakiem, redaktorem naczelnym wydawnictwa Studio Emka, „Biblioteka Analiz", nr 14, 2003, s. 4.

${ }^{67}$ E. Golębiewski, Rynek ksiązki... 2003, t. 2, s. 17.

${ }^{68}$ Ibidem, s. 18 i $30-31$.

${ }^{69}$ Ibidem, s. 30.

${ }^{70} \mathrm{~J}$. Hetman, Hurt jest jak czarna dziura. Rozmowa z Tomaszem Michałowskim, „Bil)lioteka Analiz”, nr 11, 2003, s. 4.

${ }^{71}$ R. Mendruń, $A$ strumieŕ książek plynie obok, „Biblioteka Analiz”, nr 20, 2003, s. 9. O przemianach czekających zapewne polskie hurtownie książek - zob. P. Marciszuk, Ksiegarze w Stentorze. Ostatnie ogniwo, „Biblioteka Analiz”, nr 21, 2003, s. 19. Zdaniem T. Nowaka natomiast jedynym skutecznym sposobem na zwiększenie efektyw- 
ności sprzedaży i pomniejszenie jej kosztów jest... powstanie silnego hurtu, tenże, $N a$ ksiązkowyn szlaku. Rzecz o dystrybucji, „Notes Wydawniczy”, nr 11, 2003, s. 41.

${ }^{72}$ Tenże, Taniej sie nie da, „Bibliotelka Analiz” 2004, nr 2, s. 10-12; (mf), Arvato na spot-kaniu wydawców, „Notes Wydawniczy”, nr 1, 2004, s. 5.

${ }^{73} \mathrm{~J}$. Walewska, Raport o ksiegarstwie, Warszawa 2000, s. 9.

${ }^{74}$ Ł. Golębiewski, Rynek książki... 2003, t. 2, s. 85.

${ }^{75}$ Ibidem, s. 87.

${ }^{76}$ B. Klukowski, Ksiazika..., s. 33-35, 80 i 86; T. Woll, op. cit., s. 15.

${ }^{77}$ B. Klukowski, Bertelsmann $i$ Weltbild, czyli Niency w Polsce, „Notes Wydawniczy", nr 3/4, 2001, s. 20.

${ }^{78}$ Ł. Gołębiewski, Rynek ksiązki... 2003, t. 2, s. 197.

${ }^{79}$ Ibidem, s. 91; por. B. Klukowski, Sprzedaz wysylkowa, „Notes Wydawniczy”, nr 9 , 2001 , s. $20-22$.

${ }^{80}$ B. Klukowski, ibidem.

${ }^{81}$ A. Nowakowski, Zero VATowane poetami, „Notes Wydawniczy”, nr 11, 1999, s. 61.

${ }^{82} \mathrm{~J}$. Walewska, Obroty sfer ksieggarskich, „Notes Wydawniczy”, nr 11/12, 2001, s. 55. ${ }^{83}$ (Pigr), Rynek marketów. Supernarzekanie, "Biblioteka Analiz”, nr 14, 2003, s. 9.

${ }^{84}$ Ł. Gołębiewski, Rynek książki... 2003, s. 94-97.

${ }^{85}$ Ibidem.

${ }^{86}$ B. Klukowski, Sprzedaz wysylkowa..., s. 22; T. Woll, op. cit., s. 196.

${ }^{87}$ f. Gołębiewski, Rynek ksiązki... 2003, t. 2, s. 201.

${ }^{88}$ J. Mazur, Promocja, w: Encyklopedia biznesu, t. 1, Warszawa 1995, s. 658.

${ }^{89}$ Paczkarz, Plus vis quam ratio, „Biblioteka Analiz”, nr 15, 2003, s. 20.

${ }^{90} \mathrm{~J}$. Mazur, Promocja..., s. 657.

${ }^{91}$ A. Sznajder, op. cit., s. 484.

${ }^{92}$ T. Woll, op. cit., s. 162.

${ }^{93}$ P. Kotler, Marketing. Analiza..., s. 563-564.

${ }^{94}$ Ibidem.

${ }^{95} \mathrm{~J}$. Huenefeld, op. cit. s. 322; por. M. Zając, op. cit., 133-136.

${ }^{96}$ P. Kotler, Marketing. Analiza..., s. 342, 563-564; zob. tenże, Marketing od A..., s. 152-153; K. Podstawka, Praktyczny marketing. Kluczowe elementy, Rzeszów 1997 , S. 180 .

${ }^{97}$ K. Podstawka, op. cit., s. 182.

${ }^{98}$ P. Kotler, Marketing. Analiza..., op. cit., s. 563.

${ }^{99}$ T. Woll, op. cit., s. 270.

${ }^{100}$ Rzecznik prasowy a pracownik public relations, Poznań 2002, s. 3; por. J. Mazur, Promocja..., s. 660.

${ }^{101}$ A. Sznajder, op. cit., s. 486, por. M. Zając, op. cit., s. 140-141.

${ }^{102}$ J. Mazur, Promocja..., s. 660.

${ }^{103} \mathrm{~J}$. Frolow, Krótki kurs public relations, „Notes Wydawniczy”, nr 3/4, 2003, s. 41 43; nr 5, s. 27-29; nr 7/8, s. 37-39; nr 9, s. 20-23. Por. G. Kopacz, Okien PR-owca, „Press”, 2002 , nr 1, s. 80-81.

${ }^{104}$ J. Frolow, Zadnych liczb $i$ zadnych procentów, „Biblioteka Analiz”, nr 13, 2004, s. 10-13. Przestrogi przed często popełnianymi przez wydawców blędami w dziedzinie promocji wyraził J. Włodarczyk, op. cit., s. 58.

${ }^{105}$ A. Sznajder, op. cit., s. 484.

${ }^{106}$ K. Podstawka, op. cit., s. 174. 
${ }^{107}$ P. Kotler, Marketing. Analiza..., s. 564.

${ }^{108}$ Ł. Golębiewski, Rynek książki... 2003, s. 205-206.

${ }^{109}$ T. Woll, op. cit., s. 189-190; por. Jak osiaggnąć sukces w ksiegarstwie..., s. 143-150.

${ }^{110}$ Ibidem, s. 190.

111 Ibidem.

${ }^{112}$ Por. M. Świtala, op. cit., s. 55

${ }^{113}$ K. Wolff, Stereotypy a rzeczywistośc, "Notes Wydawniczy", n! 6, 2003, s. 35.

${ }^{114}$ M. Świtala, op. cit., s. 75.

${ }^{115}$ Ibidem, s. 90.

${ }^{116}$ A. Baverstock, op. cit., s. 25

${ }^{117}$ P. Kotler, Marketing. Analiza..., s. 522.

${ }^{118}$ T. Woll, op. cit., s. 14.

${ }^{119}$ J. Huenefeld, op. cit., s. 25.

${ }^{120}$ R. Lis, Amerykański sen, amerykańska lekcja, „Notes Wydawniczy”, $11 \mathrm{r} 3,1999$, s. $74-77$.

${ }^{121}$ R. Mendrun, A strumień ksiązek..., s. 9.

${ }^{122}$ M. Jaworski, Sredniookresowe trendy na rynku książki w Polsce. Co było, co nas czeka, „Biblioteka Aualiz”, n1 26, 2003, s. 8-13.

${ }^{123} \mathrm{~J}$. Frołow, Wiele przed nami [wywiad z D. Murawską], „Notes Wydawniczy”, nr 5, 2004 , s. 44.

${ }^{124}$ (RM), Więcej tirm, więcej z rynkı ksiązli;, "Biblioteka Analiz”, nr 2, 2004, s. 14.

${ }^{125}$ F. Golębiewski, Rynek ksiązki... 2003, s. 21; por. T. Nowak, Wyboiste rynku goścince, „Notes Wydawniczy”, nr 3/4, 2003, s. 39.

${ }^{126}$ P. Kotler, Marketing. Analiza..., s. 364; por. T. Nowak, Bez latwych odpowiedzi, czyli koncepcja nnarlietingu w wydawnictwie, „Notes Wydawniczy” 2003, ur 9, s. 16-19.

${ }^{127}$ M. Jaworski, op. cit., s. 12.

${ }^{128}$ Wydawcy muszą dać Intr townion szansę, „Biblioteka Analiz”, nr 7, 2003, s. 10. 